\title{
Posttraumatic basal ganglia infarction: A rare complication in a child after mild head injury
}

\section{Posttravmatik bazal ganglion infarktt: Çocukta hafif bir kafa travması sonrası gelişen nadir bir komplikasyon}

\author{
Ahmet Mete', Duçem Mete ${ }^{2}$, Sedat Işıkay ${ }^{3}$
}

\begin{abstract}
Head trauma usually causes hemorrhage, but in young children ischemia of the basal ganglia may develop. We are presenting a case of mild head injury presenting as an ischemic stroke. Bleeding was ruled out with computerized tomography (CT) and magnetic resonance imaging (MRI) revealed acute infarction in the right lentiform nucleus. Herein we aimed to emphasize that mild head trauma may cause serious consequences such as acute infarct in pediatric population.
\end{abstract}

Key words: Cerebral infarction, head trauma, traumatic stroke, magnetic resonance imaging

\section{INTRODUCTION}

Trauma can cause many vascular complications, and can lead to cerebral infarction. However, the recognition of childhood stroke is difficult and challenging. Ischemic stroke after minor head trauma is a major clinical problem and in children under 18 months of age is a rare eventuality $(<2 \%$ of all ischemic stroke in childhood). It is caused by vasospasm of the lenticulostriate arteries, frequent in childhood, which are disrupted by head injury [1]. We present a 2-year-old boy with hemiparesis due to a posttraumatic infarction in the territory of the right lenticulostriate artery.

\section{CASE REPORT}

A 2-year-old male boy was referred to our observation following a head injury involving the right

\section{ÖZET}

Kafa travması genellikle hemorajiye neden olurken, küçük çocuklarda bazal ganglia infarktı gelişebilmektedir. Bu yazıda hafif kafa travması sonrası iskemik inme gelişen vakayı sunmaktayız. Kanama bilgisayarlı tomografi ile dışlandı ve manyetik rezonans görüntülemede sağ lentiform nükleusta akut infarkt saptandı. Biz burada pediatrik popülasyonda travmanın akut infarkta varabilecek önemli sonuçlara neden olabileceğini vurgulamayı amaçladık.

Anahtar kelimeler: Serebral infarkt, kafa travması, travmatik inme, manyetik rezonans görüntüleme

temporo-occipital region. He fell from a height of approximately $50 \mathrm{~cm}$ onto a thinly carpeted floor. The child did not lose consciousness and had no history of a seizure. Almost six hours later he developed a weakness of his left arm and leg. A computed tomography (CT) scan of his brain revealed a hypodense lesion at the right lentiform nucleus. Diffusion-weighted images showed a sharply demarcated high-signal intensity lesion in similar area on T2weighted and fluid-attenuated inversion recovery sequences images, compatible with acute infarct on the territory supplied by the lateral lenticulostriate artery (Figure 1). Conservative therapy resulted in symptomatic improvements and the patient was discharged with a left hemiparesis on the tenth day of his admission.

\footnotetext{
${ }^{1}$ Gaziantep Üniversitesi, Tıp Fakültesi Radyoloji Anabilim Dalı, Gaziantep, Türkiye

${ }^{2}$ Şehitkamil Devlet Hastanesi Radyoloji Kliniği, Gaziantep, Türkiye

${ }^{3}$ Gaziantep Çocuk Hastanesi, Çocuk Nörolojisi Kliniği, Gaziantep, Türkiye
}

Yazışma Adresi /Correspondence: Ahmet Mete, 


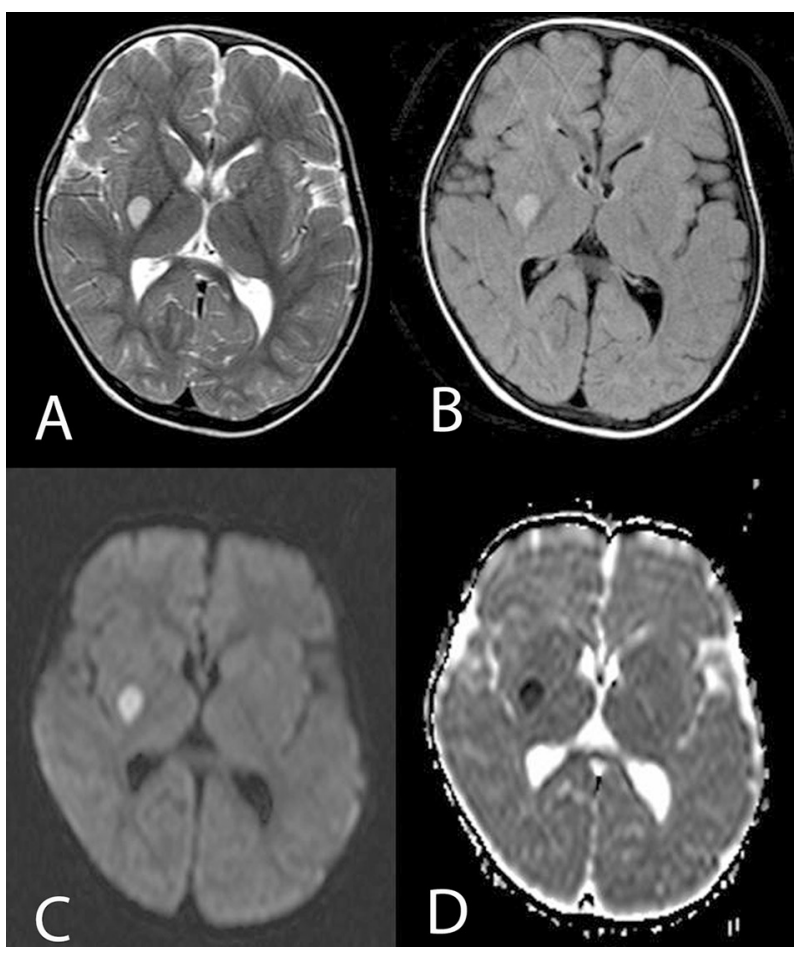

Figure 1. T2-weighted (A), FLAIR (B), and diffusion-weighted $(C)$ images showed a sharply demarcated high-signal intensity lesion and ADC (D) image showed hypointense lesion compatible with acute infarct on the territory supplied by the lateral lenticulostriate artery.

\section{DISCUSSION}

In childhood, ischemic stroke due to a mild head trauma is an exceedingly rare event, and each year 5/100000 children are affected [1]. Although rare, mild head injury can cause basal ganglia infarct, and therefore, facio-brachio-crural hemiparesis can occur. This syndrome appears to be more relevant to young children because the angle between the main middle cerebral artery and the lenticulostriate arteries is more acute, the length of these extracerebral segments also tends to be shorter, and these arteries are functional end arteries [2]. Any trauma of the brain may lead to disruption of the vessel between the mobile extracerebral portion and the fixed intracerebral portion. The territory of this lenticulostriate branches is thus mechanically vulnerable to ischemia as a result of vascular occlusion or mechanical spasm following arterial disruption, even following mild head injury $[3,4]$. Also mild head trauma may lead to intimal trauma and subsequent thrombosis. Secondary causes responsible for cerebral ischemic lesions in young children are attributable to bleed- ing, traumatic dissection of the common carotid, internal carotid arteries or of the vessels of circle of Willis, congenital predisposition to rupture of cervical or intracranial arteries, emboligen heart disease and congenital thrombophilia $[5,6]$. It is mandatory to exclude all possible secondary causes before classifying a cerebral infarction in children as idiopathic. Therefore CT scan, brain MRI with Diffusion Weighted Imaging (DWI), angio-MRI, carotid color doppler imaging, echocardiogram and complete blood work-up should be performed.

In conclusion, mild head injuries may cause cerebral infarction at the internal capsule due to mechanical vasospasm or thrombosis of the perforating vessels, although ischemic symptoms are not so severe and tend to disappear in the early period by conservative therapy. Rapid reversal or attenuation of neurological symptoms may be attributed to the resolution of vasospasm. However, the healing process despite an infarction may be the result of the childhood neuronal plasticity, a theory which was supported by research reports [7-9]. Radiologists and pediatricians must be aware of lenticulostriate infarction as a rare complication of mild trauma in young children and early diagnosis by performing DWI can prevent possible permanent neurological damage.

\section{REFERENCES}

1. Shaffer L, Rich PM, Pohl KR, Ganesan V. Can mild head injury cause ischemic stroke? Arch Dis Child 2003;88:267-269.

2. Umansky F, Gomes FB, Dujovny M, et al. The perforating branches of the middle cerebral artery. A microanatomical study. J Neurosurg 1985;62:261-268.

3. Dharker SR, Mittal RS, Bhargava N. Ischemic lesion in basal ganglia in children after minor head injury. Neurosurgery 1993;33:863-865.

4. Kuroiwa T, Tanabe H, Takatsuka H, et al. Paramedian thalamic infarction following blunt head injury. Neurol Med Chir (Tokyo) 1994;34:20-22

5. Kieslich M, Fiedler A, Heller C, et al. Minor head injury as cause and co-factor in the aetiology of stroke in childhood: a report of eight cases. J Neurol Neurosurg Psychiatry 2002;73:13-16.

6. Fullerton HJ, Johnston SC, Smith WS: Arterial dissection and stroke in children. Neurology 2001;57:1155-1160.

7. Anderson VA, Catroppa C, Dudgeon P, et al. : Understanding predictors of functional recovery and outcome 30 months following early childhood head injury. Neuropsychology 2006;20:42-57.

8. Kochanek PM. Pediatric traumatic brain injury: quo vadis? Dev Neurosci 2006;28:244-255.

9. Seçkin H, Demirci AY, Değerliyurt A, et al. Posttraumatic infarction in the basal ganglia after a minor head injury in a child: case report. Turk Neurosurg 2008;18:415-419. 